\title{
Implikasi Postfeminisme Terhadap Degradasi Moral Bangsa
}

\author{
H. Abd. Muis Said \\ Dosen Fakultas Tarbiyah dan Keguruan \\ UIN Alauddin Makassar
}

\begin{abstract}
Post-feminist discourse whose features are almost the same as postmodernist theory make life style also influenced. Consumerism, hedonism, as well as various doctrines of feminism that are not in line with the concept of religion, will result in the dilapidation of one's behavior. What's worse is when women are always isolated from their functions and roles. Therefore, women must come out of a humble stigma that has already been constructed in the community and motivates from and their people so that they do not participate in the paradigm of thinking of postfeminism which leads to dichotomy.
\end{abstract}

Keywords: Post-feminist, Moral Degradation

\section{Latar Belakang}

Kaum feminisme ortodoks cenderung melihat perempuan sebagai mahluk inferior dan korban laki-laki ini tidak dapat diterima perempuan muda di beberapa negara maju khususnya pada era 90-an dan 2000-an. Semboyan feminisme yang melekat pada pendahulu mereka di era 70-an didataran Amerika dan Inggris membuat generasi muda "bosan" dengan Feminisme. Feminisme seakan menjadi label istimewa untuk menuduh orang lain menjadi melakukan hal sebailknya secara moral dan politik.

Kawula muda menjadi cikal bakal kelompok Post-feminist. Para aktifis dalam periode post-feminisme menggunakan metode dekonstruksi dalam melihat teks-teks ketertindasan perempuan sebagai cirikhas era postmo. Kelompok ini membawa paradigma baru dalam feminisme,dari perdebatan seputar kesetaraan menuju perbedaan yang mencolok. Sebagaian besar menganggap bahwa Indonesia - sebagai salah satu daru dunia ke tiga - masih mengalami euforia Feminisme. Ironisnya, euforia ini terkesan norak dengan situasi yang baru dan terkesan reaktif seperti halnya di barat pada era 60-an dan 70-an. Yang ganjal adalah ketika Eropa mulai jenuh dengan solusi feminism yang justru menciptakan polemik baru, justru di Indonesia masih mengelu-elukannya. 


\section{An-Nisa', Volume XI Nomor 1 Januari 2018}

Kultur pop, seperti hedonisme dan konsumerisme dalam feminisme, dalam buku Aquarini Priyatna Prabasmoro dengan judul Kajian Budaya Feminis: Tubuh, Sastra dan Budaya Pop $^{141}$ memaparkan bahwa ada beberapa tema yang perlu dikaji terkait era kekinian seperti komersialisasi tubuh perempuan (seksualitas), komersialisasi tubuh perempuan dalam dunia entertain dan iklan, serta kapitalisasi perempuan dalam dunia fashion.

Sejak adanya islam secara prinsipil dan normatif, konsep ini sangat menghargai perempuan bahkan mengangkat derajatnya, serta membuatnya lebih produktif. Hal yang kontradiktif terjadi pada masyarakat dengan adanya konstruk yang mendiskriminasi perempuan serta melecehkannya. Perempuan di lain sisi adalah pembentuk peradaban. Jika perempuan lemah, rusak, serta kehilangan identitas dirinya, maka bisa dipastikan bahwa degradasi moral bangsa ada di ujung tanduk. Untuk itu diperlukan upaya menegakkan keadilan dan merekonstruksi hubungan gender dalam islam dan secara universal dengan lebih adil. Perlu ditegaskan bahwa memperjuangkan posisi perempuan dalam islam dan masyarakat serta penindasan sama sekali bukanlah perjuangan perempuan melawan laki-laki.

Olehnya itu persoalan penindasan dan diskriminasi bukan dilegitimasi sebagai persoalan kaum laki-laki, melainkan persoalan sistem dan struktur ketidakadilan masyarakat dan gender, yang salah satu legitimatornya adalah keyakinan agama dan hukum negara yang bias gender. Karena itu perlu diusahakan adanya gerakan "transformasi" dan bukan gerakan untuk membalas dendam kepada kaum laki-laki, melainkan gerakan menciptakan suatu sistem hubungan laki-laki dan perempuan yang lebih adil dan ideal. Selain itu, dibutuhkan advokasi kesadaran tentang gender dan mengasah produktivitas diri agar bisa mewujudkan bangsa yang berkarakter kuat serta produktif.

Perlu adanya solusi terhadap budaya postfeminist terkhusus bagi kaum perempuan sejak dini dengan penanaman karakter dan pembinaan ketika remaja. Hal ini diharapkan bisa menjadi bekal ketika beranjak dewasa dan mengarungi bahtera rumah tangga dan bergerak di masyarakat luas. Tantangan era digital serta pengaruh pemikiran postfeminisme terhadap pola dan gaya

${ }^{141}$ Aquarini Priyatna Prabasmoro. Kajian Budaya Feminis: Tubuh, Sastra dan Budaya Pop.(Yogyakarta: Jalasutra, 2006), hal. 103 
hidup wanita saat ini perlu terus direkonstruksi dan dibenahi. Karena itu beberapa solusi dan rekonstruksi paradigm ditawarkan pada akhir artikel ini.

\section{Pembahasan}

\section{a. Teori Dasar Postfeminisme}

Posfeminisme merupakan suatu istilah yang saat ini ramai diperbincangkan. Istilah ini dapat merupakan reaksi buruk (back lash) dari media massa terhadap perlawanan kepada perjuangan feminism. Selama ini secara tradisional, kehidupan masyarakat masih bersifat patriarki dan memarginalkan peranan kaum perempuan. Namun seiring dengan berjalannya waktu, wanita sudah mulai melakukan pergerakan maju dan mulai meniggalkna kesan bahwa wanita itu lemah dan hanya bias "patuh" kepada keputusan pria.

Seorang kritikus feminis, Judith Stacey, mengungkapkan bahwa istilah "posfeminis" merupakan sebuah istilah menarik untuk didiskusikan. Sampai saat ini belum banyak literature yang membahas masalah ini dan bagaimana awalnya istilah ini bisa muncul. Posfeminisme bukannya anti feminis, tetapi hanya untuk membuktikkan asumsi yang dipercaya oleh para feminis gelombang kedua tahun 1960 setelah berakhirnya Perang Dunia II bahwa ada penindasan patriarki terhadap kaum perempuan dan bermunculannya banyak negara-negara baru dengan pemikiran-pemikiran mereka sendiri. Marginalisasi peran perempuan dalam berbagai aspek kehidupan, khususnya ekonomi dan politik, merupakan bukti konkret yang diberikan kaum feminis.

Perkembangan teori feminisme di awal tahun 80-an mengarah pada teori feminisme gelombang ketiga dimana teori postmodernisme, global, dan multikultural serta ekofeminisme memainkan peranan yang penting dalam dunia akademik ${ }^{142}$. Sehingga bisa dipahami secara implisit bahwa posfeminisme ada kaitannya dengan wacana postmo.

Posfeminisme hanyalah berfungsi sebagai penggerak perubahan pola berpikir kaum perempuan. Bukan berarti anti feminis, tetapi hanya menunjukkan bahwa ada perlawanan dari kaum perempuan atau feminis di segala bidang, yang selama ini dianggap hanya dikuasai oleh

\footnotetext{
${ }^{142}$ Agus Purwadianto, et.al. Jalan Paradoks: Visi Baru Fritjpf Capra tentang Kearifanu dan Kehidupan Modern. (Bandung: Mizan Media Utama. 2004). hal.34
} 


\section{An-Nisa', Volume XI Nomor 1 Januari 2018}

pria. Posfeminisme ini coraknya juga dipengaruhi oleh wacana postmo. Yasraf menyatakan bahwa adanya idiom estetik postmodernisme ${ }^{143}$ tidak terlepas dari perkembangan masyarakat konsumer, kondisi ruang hiperialitas, kapitalisme global sebagai bentuk kekuasaan serta berbagai ideologi yang mengikutinya.

Sementara Jencks mendefinisikan postmo sebagai eklmaektikisme atau adhoisme radikal $^{144}$. Bagi Jean Francois Lyotard-seorang pemikir postmodernis Perancis- beranggapan bahwa postmodernis adalah bagian dari modern, dan perbedaannya terletak pada model representasi dari teks atau karyanya ${ }^{145}$.

Pandangan mengenai posfeminisme hanyalah sebuah bentuk dari perlawanan kaum perempuan terhadap budaya patriarki sebagaimana yang Ann Brooks (2005) ungkapkan, "Faktanya, perempuan sendiri tersebar dalam berbagai kelas sosial, klasifikasi rasial dan etnis, komunitas seksual, subkultur, dan agama yang artinya tiap perempuan akan mengalami dan merasakan pengalaman sosial dan kesadaran personal yang cukup bervariasi.”

Contoh yang terlihat adalah ketika kita temukan bagaimana peranan perempuan dalam film atau cerita-cerita pada saat sekarang ini. Walaupun seorang wanita berperan sebagai pemeran seperti "pahlawan wanita" atau "wanita super" yang menang dalam pertarungan, tetap saja wanita itu pada akhirnya tunduk pada laki-laki. Ini menunjukkan bahwa budaya patriarki masih cukup kuat mendominasi dalam segi apapun dan diperlihatkan sebagai kebenaran umum.

Dalam hal hubungan posfeminisme dengan politik kebudayaan, terdapat berbagai perbedaan dan perdebatan. Ini disebabkan karena banyak para teoritikus atau kritikus yang merupakan penullis laki-laki, sehingga mereka dapat memonopoli bidang mereka dan meminoritaskan para penulis perempuan atau feminis. Terlepas pada kecenderungan luas atau tidaknya nalarnya, perempuan tidak memiliki ruang yang sama dalam menyampaikan opininya.

Gerakan Perempuan yang muncul pada era 60-an sampai 70-an memungkinkan para penulis perempuan dan feminis untuk mengungkapkan ide-ide dan gagasan mereka untuk

\footnotetext{
${ }^{143}$ Yasraf Air PIliang. Hipersemiotika: Tafsir Cultura Studiesatas Matinya Makna.( Yogyakarta: Jalasutra, 2003), hal.118

${ }_{144}$ Charles Jencks. The Language of Post-modern Architecture, (Academy Press: London. 1977), hal. 92

145 Jean Francois Lyotard. The Postmodern Condition: A report on a Knowledge.(Manchester University Press. 1989). hal.81
} 
wacana yang berbau politik, ekonomi dan budaya. Peran perempuan yang muncul ini sekaligus untuk "mematahkan" anggapan bahwa wanita hanya bisa bisu dan tidak berkreasi atau bernalar kritis seperti para penulis pria. Lantas bagaimana posfeminisme bisa mempresentasikan unsurunsur dari budaya pop? Banyak para penulis atau peneliti yang memakai Madonna sebagai contoh kasus dalam hal posfeminisme dan budaya. Madonna sebagai seorang public figure dikenal sebagai seorang wanita yang maju, berani, dan banyak membawa perubahan pandangan khalayak terhadap wanita kala itu.

Secara garis besar, berikut penjabaran terkait fase perkembangan feminisme yang terbagi menjadi 3 fase antara lain ${ }^{146}$ :

\section{Gelombang Awal}

Sejarah Feminisme sebagai filsafat dan gerakan dilacak dalam sejarah kelahirannya dengan kelahiran era Renaissance di Eropa yang dipelopori oleh Lady Mary Wortley Montagu dan Marquis de Condorcet pada tahun 1785. Menjelang abad 19 feminisme lahir menjadi gerakan yang cukup mendapatkan perhatian dari para perempuan kulit putih di Eropa. Perempuan di negara-negara penjajah Eropa memperjuangkan apa yang mereka sebut sebagai universal sisterhood. Kata feminisme dikreasikan pertama kali oleh aktivis sosialis utopis, Charles Fourier pada tahun 1837.

Pada awal gerakan ini memang diperlukan pada masa itu, dimana ada masa-masa pemasungan terhadap kebebasan perempuan. Sejarah dunia menunjukkan bahwa secara umum kaum perempuan (feminin) merasa dirugikan dalam semua bidang dan dinomor duakan oleh kaum laki-laki (maskulin) khususnya dalam masyarakat yang patriarki sifatnya. Dalam bidangbidang sosial, pekerjaan, pendidikan, lebih-lebih politik hak-hak kaum ini biasanya memang lebih inferior ketimbang apa yang dapat dinikmati oleh laki-laki, apalagi masyarakat tradisional berorientasi Agraris cenderung menempatkan kaum laki-laki di depan, di luar rumah dan kaum wanita pada rana domestik.

\footnotetext{
${ }^{146}$ Ulwiyatur Rif'ah. Feminisme dan Post Feminisme. http://karsasoeper.blogspot.com/2014/03/feminisme-danpost-feminisme.html . 2014. Diakses pada tanggal 04 Januari 2019
} 


\section{An-Nisa', Volume XI Nomor 1 Januari 2018}

Pada abad ke 18 sejalan terhadap pemberantasan praktek perbudakan, hak-hak kaum perempuan mulai diperhatikan, jam kerja dan gaji kaum ini mulai disesuaikan dan mereka diberi kesempatan ikut dalam pendidikan dan diberi hak pilih seperti yang dinikmati oleh kaum lakilaki. Secara umum pada gelombang pertama dan kedua hal-hal berikut ini yang menjadi momentum perjuangannya antar lain: gender inequality, hak-hak perempuan, hak reproduksi, hak berpolitik, peran gender, identitas gender dan seksualitas. Gerakan feminisme adalah gerakan pembebasan perempuan dari segi rasisme, stereotyping, seksisme, dan penindasan terhadap perempuan.

\section{Gelombang Kedua}

Pasca berakhirnya PD II, ditandai dengan lahirnya negara-negara baru yang terbebas dari penjajah Eropa, lahirlah Feminisme fase kedua pada tahun 1960. Dengan puncak diikutsertakannya perempuan dalam hak suara parlemen. Pada tahun ini merupakan awal bagi perempuan mendapatkan hak pilih dan selanjutnya ikut mendiami ranah politik kenegaraan. Dalam gelombang kedua ini dipelopori oleh para feminis Perancis seperti Helene Cixous (seorang Yahudi kelahiran Aljazair yang kemudian menetap di Perancis) dan Julia Kristeva (seorang Bulgaria yang kemudian menetap di Perancis) bersamaan dengan kelahiran dekonstruksionis, Derrida.

Dalam the Laugh of the Medusa, Cixous mengkritik logosentrisme yang banyak didominasi oleh nilai-nilai maskulin. Walaupun bukan white-Anglo-American-Feminist, dia menolak esensialisme yang sedang marak di Amerika pada waktu itu. Julia Kristeva memiliki pengaruh kuat di wacana pos-strukturalis yang sangat dipengaruhi oleh Foucault dan Derrida. Secara lebih spesifik, banyak feminis-individualis kulit putih, meskipun tidak semua, mengarahkan obyek penelitiannya pada perempuan-perempuan dunia ketiga seperti Afrika, Asia dan Amerika Selatan. Dalam berbagai penelitian tersebut, telah terjadi pretensi universalisme perempuan sebelum memasuki konteks relasi sosial, agama, ras dan budaya. Walaupun agama ${ }^{147}$ pada gilirannya menjadi bahan kajian feminisme, sehingga tidak ada agama yang tidak punya problem dengan kaum perempuan.

${ }^{147}$ Abdul Muta'al al-Jabari. Al Mar'ah fi Tashawwur al - Islam (Cet.I; Kairo: Maktabah Wahdah, 1993), hal.43 
Amerika sebagai sekedar kebangkitan anglo-white-american-feminism tidak mampu mengakomodir kehadiran blackfemale dalam kelahirannya. Banyak kasus menempatkan perempuan dunia ketiga dalam konteks "all women". Dengan apropriasi bahwa semua perempuan adalah sama. Dalam beberapa karya sastra novelis perempuan kulit putih yang ikut dalam perjuangan feminisme masih terdapat lubang hitam, yaitu: tidak adanya representasi perempuan budak dari tanah jajahan sebagai Subjek. Penggambaran pejuang feminisme adalah yang masih mempertahankan posisi budak sebagai yang mengasuh bayi dan budak pembantu di rumah-rumah kulit putih. Perempuan dunia ketiga tenggelam sebagai yang tidak memiliki politik agensi selama sebelum dan sesudah perang dunia kedua.

\section{Gelombang Ketiga}

Keberhasilan gelombang kedua itulah yang mengispirasi perempuan dunia pertama melihat bahwa mereka perlu menyelamatkan perempuan-perempuan dunia ketiga, dengan asumsi bahwa semua perempuan adalah sama. Dengan asumsi ini, perempuan dunia ketiga menjadi obyek analisis yang dipisah dari sejarah kolonialisasi, rasisme, seksisme, dan relasi sosial. Gelombang ketiga, yang dimulai pada tahuan 1990-an sering diasosiasikan sebagai pintu masuk dari ide-ide post-struktural dan posmodern, sebagai feminisme yang lebih berbeda.

Sepanjang gelombang-gelombang kedua dan ketiga, ketertarikan para feminis pada isu ketidaksetaraan, kemiskinan, dan relasi-relasi gender memproduksi tubuh yang signifikan terhadap ide-ide kritis mengenai pembangunan dan isu-isu yang diangkat oleh para feminis secara secara signifikan berdampak pada agensi-agensi internasional yang mengurusi masalahmasalah pembangunan menuju pada hal yang lebih luas bahwa teori feminis tentang pembangunan sekarang membentuk sistem konsep-konsep, wacana-wacana, dan praktik-praktik yang diakui.

Praktik feminis kontemporer diantara para aktivis dan akademisi telah secara partikular dipengaruhi oleh debat-debat yang dimulai oleh perempuan kulit berwarna dunia pertama dan perempuan ketiga mulai pada akhir tahun 1970-an. Sebagai pernyataan awal dari perkumpulan Combahee River (1984) mempertanyakan ide atau gagasan tentang identitas perempuan pada umumnya sebagai sebuah basis strategi politik. Para penyair dan pengarang, terutama Bell 


\section{An-Nisa', Volume XI Nomor 1 Januari 2018}

Hooks daAudre Lordre, mengkritisi gerakan perempuan karena mengesampingkan (isu-isu tentang) perbedaan seksual, rasial, dan kelas.

Gerakan-gerakan perempuan menjadi terikat melalui jaringan-jaringan menuju sesuatu yang erat kaitannya dengan praktik politik pada umumnya, tapi tidak lebih lama dipersatukan oleh suatu kepercayaan dalam karakteristik-karakteristik universal atau dipimpin oleh perempuan Barat yang progresif dalam gerak menuju pada emansipasi global. Secara khusus, Lorde, Mohanty, dan lainnya menyebut hal tersebut sebagai pergantian dramatis dalam praktik politik kolektif dan dalam pendirian para perempuan di Dunia Ketiga.

Namun, sepanjang PBB mengumumkan kepada para perempuan akan posisi mereka yang sebenarnya tambah parah, dalam hal penurunan akses terhadap sumber daya, nutrisi, dan pendidikan, dan dalam hal beban kerja yang semakin meningkat. Kegagalan ini mendramatisasi batasan kemanjuran dari pendekatan integrasionis, dan meradikalisasi studi tentang perempuan dan (and) pembangunan (Sen dan Grown 1987). Pada konferensi internasional tahunan perempuan yang diadakan di Meksiko 1975, dan di konferensi perempuan pertengahan dekade yang diadakan di Kopenhagen 1980, perdebatan panas memuncak seputar isu-isu yang relevan mengenai teori-teori feminis.

Feminisme bergeser dari yang umumnya kepentingan para perempuan Eropa untuk suatu gerakan yag heterogen, menuju pada definisi yang lebih meluas merefleksikan keterlibatan yang lebih baik melalui organisasi-organisasi regional di negara-negara dunia ketiga. Pada permulaan tahun 1980-an perempuan Dunia Ketiga mengemukakan teori-teori baru pembangunan yang merangkul feminisme, sementara konferensi-konferensi perempuan tentang pemberdayaan perempuan sebagai agen-agen, daripada melihat mereka sebagai masalah-masalah, dari pembangunan (Bunch dan Carillo 1990).

Konferensi perempuan dunia keempat pada tahun 1995 di Beijing, menghasilkan Platform tantang Aksi terhadap hak-hak perempuan: hak-hak pendidikan, makanan, kesehatan, kekuatan politis yang lebih baik, dan bebas dari kekerasan (Bunch, et al. 1995). Para perempuan di Dunia Ketiga telah mengorganisir diri untuk menghindari ancaman-ancaman dalam bidang 
ekonomi, lingkungan, hukum, budaya dan fisik, dan juga menentang bentuk-bentuk kediktatoran, militerisme, fundamentalisme, ketergantungan ekonomi, dan kekerasan terhdap perempuan. .

Tengky Widjanarkoe mengungkapkan pada sekitar abad ke-20 muncul sosok perempuan yang lebih tangguh, wanita yang merasa memiliki segala-galanya, wanita yang merasa lebih dari laki-laki. Dan fenomena itu sering disebut "Postfeminisme". Penyampaian feminisme sudah sering ditemukan walaupun melalui ketidaksengajaan. Misalnya Wanita postfeminis bisa kita lihat dalam film "Sex and the city", dalam film tersebut terdapat empat tokoh wanita yang bisa dikatakan postfeminis). Dalam film indonesia pada film Naga bonar Jadi 2, Dalam salah satu dialognya, karakter Naga Bonar berucap: "Perempuan tetap perempuan; ingin ditinggikan sebenang."

Komentar tersebut bisa dimaknai sebagai wujud keinginan wanita yang ingin di hargai. Wanita yang tak ingin hanya tunduk kepada sistem yang selama ini mengikatnya. Perempuan tak lagi diikat oleh ego laki-laki. Barangkali juga, itulah sikap yang mesti diambil oleh seorang lakilaki menghadapi perempuan. Perempuan adalah manusia yang punya rasa, cipta, karsa seperti juga dimiliki laki-laki. Ia adalah tonggak peradaban bangsa, aset yang amat bernilai dan tenaga penggerak kemajuan. Perempuan merupakan benteng pertahanan moral dalam masyarakat yang berubah dan sering dilanda kegawatan dan kemelut sosial. Dia juga adalah sang dewi yang menjadi sumber inspirasi dan kasih sayang serta pembinaan masyarakat secara universal.

b. Analisis Penyebab Degradasi Moral Bangsa

Gerakan Indonesia Beradab (GIB) ${ }^{148}$ dalam kongres pertamanya menganalisa bahwa ada beragam Faktor Penyebab Degradasi Moral Bangsa antara lain adalah ketahanan keluarga. Sebagai pondasi pertama anak, orang tua memegang peranan penting untuk membentengi anak dari pengaruh negatif yang dapat mengikis moral anak. Ketika ketahanan keluarga rapuh, pengaruh lingkungan yang tidak baik akan memperburuk perilaku atau moral anak.

Beberapa 'ancaman' yang umum didapati oleh masyarakat khususnya generasi muda saat ini ialah minuman keras, narkoba serta ponrografi. Kekerasan pada anak, kekerasan seksual

\footnotetext{
${ }^{148}$ Dwi Murdaningsih . Berita Dunia Islam Nusantara. https://khazanah.republika.co.id/berita/dunia-islam/islamnusantara/16/07/22/oapg0j368-lima-faktor-penyebab-degradasi-moral-bangsa . 2016. Diakses pada tanggal 05 Januari 2019
} 


\section{An-Nisa', Volume XI Nomor 1 Januari 2018}

hingga penyimpangan seksual juga menjadi permasalahan serius yang patut dicari jalan keluarnya secara bersama-sama.

Ada pula masalah-masalah moral perilaku yang sifatnya lebih menjadi masalah gangguan perilaku, gangguan jiwa. Yang tak kalah penting, faktor lembaga pendidikan juga memegang peranan penting dalam mengembalikan bangsa Indonesia menjadi bangsa yang beradab. Lembaga pendidikan ini tak hanya meliputi sekolah dan pendidik tetapi juga masjid sebagai pusat penegakkan adab. Masalah ekonomi dan juga (faktor) hukum juga harus dilihat apakah sudah membantu penegakan adab atau moral itu sendiri.

c. Kiat rekonstruksi postfeminisme dalam menjawab polemik kebangsaan dan keagamaan

Teori-teori feminis yang muncul berupaya untuk memberi penjelasan mengenai penindasan terhadap perempuan. Di samping pusat perhatian dari gelombang kedua feminisme adalah bagimana perempuan dipandang sebagai korban, tetap saja hingga saat ini kondisi perempuan sebagai korban yang tertindas membuat perempuan kehilangan suaranya atau tersunyikan seakan dibungkam oleh pemasungan patriarkal.

Penting bagi perempuan untuk melihat potensi dirinya untuk merahi kekuatan dan keluar dari posisi "the victim" atau korban/ inferior. Perempuan harus berani keluar dari prespektif dominan tentang keburukan dan kelemahan perempuan dengan memiliki wawasan luas yang mampu menentang dominasi patriarki pada konstruksi sosial budaya.

Hal ini tak mudah untuk dijalani. Belenggu pemaknaan dominan terkait posisi objek perempuan yang sudah demikian merasuk di dalam diri perempuan. Subjektiftas seorang perempuan baru bisa dianggap sebagai "normal", jika dia bisa melakukan berbagai persyaratan sikap (movement) dan perilaku yang secara sosial dianggap layak bagi perempuan, itupun selama tidak melanggar kodrat fitrawinya.

Kondisi tersebut sesuai pendapat Foucault yang memandang subjektifitas merupakan hasil dari hubungan kuasa dan subordinasi yang terjadi di dalam suatu masyarakat. Foucault yang memandang subjektifitas merupakan hasil dari hubungan kuasa dan subordinasi yang terjadi di dalam suatu masyarakat (Mansfield, 2001). Foucault, seperti dikutip oleh Mansfield 
(2001), menyatakan bahwa pembentukan "subyek" itu dikontrol secara terus menerus melalui tiga hal:

a) Individualise adalah bagaimana perempuan dikonstruksikan sebagai makhluk yang berbeda. . Dalam pemahaman seperti ini, pola berpikir oposisi biner yang membedakan laki-laki dengan perempuan dikembangkan.

b) Normalise yaitu seperangkat batasan perilaku yang harus dipatuhi oleh perempuan.

c) Hierarchise adalah aplikasi norma yang bisa digunakan untuk membandingkan perempuan yang satu dengan perempuan yang lain berdasarkan kepatuhannya terhadap norma yang berlaku.

Sedangkan menjadi ibu menurut Foucault adalah salah satu kesempatan perempuan untuk keluar dari dominasi dan memperoleh kuasa. Keluar dari konstruk kuasa pemerintah atau atasan jika bekerja di ruang public.

Kaum feminis menciptakan konstruksi perempuan ideal yang berbeda (alternatif) dari yang secara sosial dianggap normal ${ }^{149}$. Lagu-lagu mereka menunjukkan bahwa mereka ingin menciptakan identitas alternatif dari perempuan yang selama ini dikonstruksi sebagai pasif, lembut, dan mengalah. Bagi mereka, perempuan sudah saatnya untuk melawan dan berani bersuara terhadap kekerasan yang dialaminya, seperti yang terlihat pada lirik lagu dari Bikini Kill berikut ini:

\author{
Rebel girl, Rebel girl \\ Rebel girl you are the queen of my world \\ Rebel girl, Rebel girl \\ I know I wanna take you home \\ I wanna try on your clotes (Rebel Girl, Bikini Kill)
}

Lirik lagu Rebel Girl tersebut menunjukkan bahwa yang perempuan yang berani menentang dominasi layak untuk menjadi idola atau merupakan sosok yang bisa menjadi panutan dan diikuti. Alternatif pemikiran seperti ini layak untuk dikaji secara mendalam di

\footnotetext{
149 Hapsari Dwiningtyas Sulistyani. "Korban dan kuasa" di dalam kajian kekerasan terhadap perempuan", ejournal. Undip,ac.id. vol. 32, 2011, hal.22
} 


\section{An-Nisa', Volume XI Nomor 1 Januari 2018}

dalam penelitian komunikasi jender, jadi yang dianalisis tidak hanya berkutat pada bagaimana media dominan mengeksploitasi dan merendahkan perempuan. Analisis atau penelitian yang menunjukkan berbagai perlawanan perempuan akan lebih bisa membuka alternatif pemikiran dan juga memberikan pemahaman mengenai potensi perempuan untuk meraih kuasa, asalkan tidak keluar dari kodrat sebagai perempuan.

Karena itu, untuk menjembatani antara wacana postfeminisme dan terbinanya karakter sejak dini, adalah dengan menanamkan pendidikan yang ada hubungannya dengan moral serta karakter sejak dini. Supaya ketika generasi muda saling berintraksi di masyarakat, tidak akan terjadi pelecehan, penindasan, ataupun kekerasan hanya karena perbedaanu gender.

Dalam Undang-undang Republik Indonesia No. 20 tahun 2003 tentang sistem pendidikan nasional, Bab 1 pasal 1 ayat 1 dikatakan bahwa Pendidikan adalah usaha sadar dan terencana untuk mewujudkan suasana belajar dan proses pembelajaran agar peserta didik secara aktif mengembangkan potensi dirinya untuk memiliki kekuatan spiritual keagamaan, pengendalian diri, kepribadian, kecerdasan, akhlak mulia, serta keterampilan yang diperlukan dirinya, masyarakat, bangsa, dan negara.

Sedangkan pada Bab II pasal 3 dikatakan bahwa -Pendidikan berfungsi mengembangkan kemampuan dan membentuk watak serta peradaban bangsa yang bermanfaat dalam rangka mencerdaskan kehidupan bangsa, bertujuan untuk berkembangnya potensi pendidikan agar menjadi manusia yang beriman, bertakwa kepada Tuhan Yang Maha Esa, berakhlak mulia, sehat, berilmu, cakap, kreatif, mandiri, dan menjadi warga negara yang demokratis serta bertanggung jawab. Maka inti dari pendidikan adalah pembentukan karakter, untuk mendewasakan manusia dengan sikap, perilaku, dan moral yang baik sehingga lahirlah generasi madani.

Apabila dikaitkan dengan pendapat para ahli, pendidikan karakter mengacu kepada pembentukan watak dan kepribadian. Salah satunya yaitu menurut Lickona mengatakan bahwa pendidikan karakter adalah tentang menjadi suatu sekolah karakter, suatu tempat yang mendahulukan karakter ${ }^{150}$.

\footnotetext{
${ }^{150}$ Lickona, Thomas. Pendidikan Karakter Dalam Pengelolaan Kelas Sekolah. (Bantul: Kreasi Wacana, 2014$)$, hal. 3
} 
Akhmad sudrajat (dalam Aunillah ${ }^{151}$ ), supaya kita lebih memahami makna pendidikan karakter, kita mesti mengerti makna dari karakter itu sendiri terlebih dahulu. Pengertian karakter menurut pusat bahasa Depdiknas adalah bawaan, hati, jiwa, kepribadian, budi pekerti, prilaku, personalitas, sifat, tabiat, tempramen, dan watak. Sementara itu, yang disebut dengan karakter yaitu kepribadian, berperilaku, bersifat, bertabiat, dan berwatak.

Helen G. Douglas (dalam Samani ${ }^{152}$ ) mengatakan "Character isn't inherited. One builds its daily by the way one thinks and acts, thought by thought, action and action". Artinya bahwa karakter tidak diwariskan, tetapi sesuatu yang dibangun secara berkesinambungan hari demi hari melalui pikiran dan perbuatan, pikiran demi pikiran, tindakan demi tindakan.

Hornby \& Parnwell (dalam Majid ${ }^{153}$ ) karakter adalah kualitas mental atau moral, kekuatan moral, nama atau reputasi. Hermawan Kertajaya (2010: 3) mendefinisikan karakter adalah — ciri khas yang dimiliki oleh suatu benda atau individu. Ciri khas tersebut adalah asli dan mengakar pada kepribadian benda atau individu tersebut dan merupakan - mesin pendorong, bagaimana seorang bertindak, bersikap, berujar, dan merespon sesuatu.

Dengan pendidikan karakter, peradaban mulia suatu bangsa dapat tercapai karena seperti yang dikatakan oleh Aqib ${ }^{154}$ pendidikan karakter lebih menekankan kepada pembentukan potensi dasar seperti:

1. Membangun iman. Dengan ini akan lahir pribadi-pribadi yang dapat mengendalikan diri dan meyakini bahwa apa yang mereka lakukan kelak akan dimintai pertanggungjawaban oleh Allah Swt. Dari pancaran keimanan ini muncul pribadi-pribadi yang jujur, bertanggungjawab, amanah, dan berakhlaq mulia.

2. Memupuk akhlak. Dengan memupuk akhlak yang baik akan membuahkan insan-insan yang berbudi mulia Pendidikan berbasis minat dan bakat. Menempatkan seseorang sesuai dengan keahliannya dalam suatu pekerjaan.

\footnotetext{
${ }_{151}$ Aunillah, Nurla. I. Panduan Menerapkan Pendidikan Karakter di Sekolah. (Jogjakarta: Laksana, 2011) hal. 19

${ }^{152}$ Samani, Muchlas., dan Hariyanto. Konsep dan Model Pendidikan Karakter. (Bandung: Remaja Rosdakarya. 2012): hal. 41

${ }^{153}$ Majid, Abdul., dan Dian Andayani. Pendidikan Karakter Perspektif Islam. (Bandung: Remaja Rosdakarya, 2013), hal, 11

${ }^{154}$ Aqib, Zainal. Pendidikan Karakter di Sekolah Membangun Karakter dan Kepribadian Anak. (Bandung: Yrama Widya, 2012). Hal. 85
} 


\section{An-Nisa', Volume XI Nomor 1 Januari 2018}

3. Pendidikan berbasis doa dan riyadha (berlatih). Rasulullah mengajarkan bahwa doa merupakan sesuatu yang penting bagi setiap insan.

Menurut Diknas mulai tahun ajaran 2011, seluruh pendidikan di Indonesia harus menyisipkan nilai-nilai pendidikan berkarakter kepada para siswa dalam proses pendidikannya. Ada 18 nilai-nilai pendidikan karakter $^{155}$, yaitu: relijius, jujur, toleransi, disiplin, kerja keras, kreatif, mandiri, demokratis, rasa ingin tahu, semangat kebangsaan, cinta tanah air, menghargai prestasi, bersahabat/komunikatif, cinta damai, gemar membaca, peduli lingkungan, peduli sosial, dan bertanggung jawab. Selain pendidikan formal, harus juga ada advokasi mengenai anti kekerasan pada perempuan dan segala hal yang mungkin dibutuhkan untuk mereduksi ketimpangan sosial dikarenakan faktor gender dan feminism.

Keterkaitan antara isu posfeminisme yang cenderung menawarkan budaya pop atau hedonis, harus disikapi sedini mungkin. Sikap dan perilaku seseorang untuk melaksanakan tugas dan kewajibannya, yang seharusnya dia lakukan, terhadap diri sendiri, masyarakat, lingkungan (alam, sosial dan budaya), negara dan Tuhan Yang Maha Esa (sejalan dengan sila pertama Pancasila). Jika seorang generasi berkarakter maka akan menjadi pribadi yang berkualitas, cerdas secara intelektual dan juga bermoral. Ajaran moral ini pasti juga diajarkan oleh semua agama.

Ketidaksamaan fisik antara lelaki dan perempuan sama sekali tidak menghambat perempuan dalam menjalankan tugas lelaki ${ }^{156}$. Sebagai contoh, tugas menjadi pelayan Allah di Baitul Maqdis yang diberikan pada lelaki, ternyata juga bisa dilaksanakan oleh Maryam. Dan masih banyak lagi bukti bahwa agama tidak mendiskreditkan posisi perempuan hanya karena perbedaan klasifikasi gender.

Khususnya dalam ajaran islam, lelaki dan perempuan punya pembagian tugas yang sinergis dalam membangun peradaban. Lelaki dibebankan sebagai "qawwamun" setelah memenuhi dua persyaratan ${ }^{157}$, yakni:

\footnotetext{
${ }^{155}$ Windi Siti Jahroh, Nana Sutarna.Pendidikan Karakter Sebagai Upaya Mengatasi Degradasi Moral. Prosiding Seminar Nasional Inovasi Pendidikan Inovasi Pembelajaran Berbasis Karakter dalam Menghadapi Masyarakat Ekonomi ASEAN.2016, h.401

${ }^{156}$ Muhammad al-Qami, Asrar al Mar'ah al-Thibbiyah wa al-Nafsiyah (Cet.II; Kairo: Dar al-Syuruq, 1994). hal. 22

${ }^{157}$ M. Quraish Shihab, Wawasan Al-Qur'an; Tafsir M audhu'I atas Pelbagai Persoalan U mat, (Cet. XI; Bandung: Mizan, 2000), hal. 310
} 
a. Kelebihan bentuk fisik yang dimiliki laki-laki menjadi tumpuan perlindungan wanita dari ancaman fisik.

b. Kemampuan laki-laki untuk berfungsi sebagai pencari nafkah, sebagai andalan wanita untuk jaminan ketenteraman intern.

Di lain sisi, perempuan berfungsi sebagai tumpuan kelanjutan generasi mulai dari mengandung, mengasuh, dan mendidik anak. Islam tidak pernah meghalangi wanita untuk menentukan pola hidup dalam segala aktifitas kehidupan, politik, ekonomi, dan sosial selama tidak bertentangan dengan kodrat kewanitaannya sebagai sunnatullah ${ }^{158}$. Jika manusia berusaha meentang sunnatullah, maka pada saat yang sama akan terjadi kepincangan dalam menjalani roda kehidupan.

\section{Kesimpulan}

Wacana postfeminisme yang coraknya hampir sama dengan teori postmodernis membuat gaya hidup juga dipengaruhi. Konsumerisme, hedonisme, serta berbagai doktrin feminisme yang tidak sejalan dengan konsep agama, akan berakibat pada bobroknya perilaku seseorang. Budaya pop yang tidak terkontrol akan merusak tatanan hidup seseorang. Tolok ukur kebahagiaan adalah materi, pergaulan bebas, hingga di titik tertentu apabila pola pikir didominasi oleh prespektif radikal ataupun liberal, seseorang akan terjebak pada degradasi moral serta identitas. Belum lagi adanya labelisasi penindasan, inferioritas, stereotip atau merendahkan jenis kelamin tertentu akan menciptakan dalam bawah sadar bahwa konstruk sosial itu benar adanya.

Tak menutup kemungkinan, bahwa apa yang diperjuangkan oleh kaum postfeminist ada benarnya juga. Akan tetapi, jika menganggap keadilan sebagai sama persis dan menyalahi kodratnya sebagai perempuan, maka akan muncul kepincangan dalam membangun peradaban kemanusiaan. Karena itu, pembinaan moral serta karakter harus ditanamkan sejak dini agar tidak ada pelecehan, penindasan, ketimpangan ataupun kekerasan hanya karena perbedaan gender.

\footnotetext{
158 Amrah Muhammad Kasim. Wanita dalam Konteks Tekstual dan Sosial SUatu Pendekatan Linguistik atas Gender. Jurnal Piramida: Media Studi Islam danu Timur Tengah. Vol.5 No.2, 2009. hal. 125
} 
Oleh karena itu, perempuan harus keluar dari stigma yang merendahkan dirinya/prespektif dominan yang sudah terlanjur dikonstruk di masyarakat dan memotivasi dari serta kaumnya agar tidak ikut larut dalam paradigma berpikir postfeminisme yang mengarahkan pada dikotomi. Karena sebenarnya, terkadang stigma yang salah itu yang terus terbangun, walaupun pada hakekatnya sangat jauh dari filosofi penciptaan. Selain itu, pembinaan karakter harus dipupuk sejak dini agar ketika generasi berkecimpung di masyarakat, bisa saling menghormati satu sama lain, utamanya bekal dala berinteraksi secara sosial. Serta tak ada lagi stigma buruk yang menyatakan bahwa agama merendahkan perempuan, padahal aturan agama justru sangat menghargai perempuan jika dipelajari sebaik mungkin.

\section{Daftar Pustaka}

Al-Qami, Muhammad, 1994. Asrar al Mar'ah al-Thibbiyah wa al-Nafsiyah . Cet.II; Kairo: Dar al-Syuruq

Aqib, Zainal. 2012. Pendidikan Karakter di Sekolah Membangun Karakter dan Kepribadian Anak. Bandung: Yrama Widya.

Jahroh, Windi Siti Nana Sutarna. 2016. Pendidikan Karakter Sebagai Upaya Mengatasi Degradasi Moral. Prosiding Seminar Nasional Inovasi Pendidikan Inovasi Pembelajaran Berbasis Karakter dalam Menghadapi Masyarakat Ekonomi ASEAN.

Jencks, Charles. 1977. The Language of Post-modern Architecture, Academy Press: London.

Kasim, Amrah Muhammad. 2009. Wanita dalam Konteks Tekstual dan Sosial SUatu Pendekatan Linguistik atas Gender. Jurnal Piramida: Media Studi Islam dan Timur Tengah. Vol.5 No.2.

Lyotard, Jean Francois. 1989. The Postmodern Condition: A report on a Knowledge. Manchester University Press.

Majid, Abdul., dan Dian Andayani. 2013. Pendidikan Karakter Perspektif Islam. Bandung: Remaja Rosdakarya

Muchlas, Samani,., dan Hariyanto. 2012. Konsep dan Model Pendidikan Karakter. Bandung: Remaja Rosdakarya.

Murdaningsih, Dwi. 2016. Berita Dunia Islam Nusantara. https://khazanah.republika.co.id/berita/dunia-islam/islamnusantara/16/07/22/oapg0j368-lima-faktor-penyebab-degradasi-moral-bangsa. Diakses pada tanggal 05 Januari 2019

Muta'al al-Jabari , Abdul. 1993. Al Mar'ah fi Tashawwur al- Islam .Cet.I; Kairo: Maktabah Wahdah. 
Nurla, Aunillah, I. 2011. Panduan Menerapkan Pendidikan Karakter di Sekolah. Jogjakarta: Laksana.

Piliang, Yasraf Air. 2003. Hipersemiotika: Tafsir Cultura Studiesatas Matinya Makna. Yogyakarta: Jalasutra.

Prabasmoro, Aquarini Priyatna . 2006. Kajian Budaya Feminis: Tubuh, Sastra dan Budaya Pop. Yogyakarta: Jalasutra.

Purwadianto, Agus et.al . 2004. Jalan Paradoks: Visi Baru Fritjof Capra tentang Kearifanu dan Kehidupan Modern. Bandung: Mizan Media Utama

Rif'ah, Ulwiyatur. $\quad$ Feminisme dan Post $\quad$ Feminisme. 2014. http://karsasoeper.blogspot.com/2014/03/feminisme-dan-post-feminisme.html. Diakses pada tanggal 04 Januari 2019

Shihab, M. Quraish, 2000. Wawasan Al-Qur'an; Tafsir Maudhu'I atas Pelbagai Persoalan Umat, Cet. XI; Bandung: Mizan.

Sulistyani, Hapsari Dwiningtyas. 2011. Korban dan kuasa" di dalam kajian kekerasan terhadap perempuan, ejournal. Undip,ac.id. vol. 32

Thomas, Lickona,. 2014. Pendidikan Karakter Dalam Pengelolaan Kelas Sekolah. Bantul: Kreasi Wacana. 